\title{
Establishment of Leavenworth's Tickseed (Coreopsis leavenworthii) on Roadside Right-of-Ways ${ }^{1}$
}

\author{
Jeffrey G. Norcini, Anne L. Frances, Carrie Reinhardt Adams²
}

\section{Introduction}

The Florida Department of Transportation's (FDOT) roadside right-of-way (ROW) wildflower program began in 1963 (1). In addition to the aesthetic attributes of roadside wildflowers, FDOT noted that wildflower plantings would increase driver alertness. Even though fuel prices were low back in the 1960s, the FDOT also noted lower roadside maintenance costs as an advantage of roadside wildflowers. Today the economic benefit of wildflowers in roadside right of way is even more relevant because maintenance expenses are driven by higher fuel, labor, and equipment costs.

The economic value of using native wildflowers in ROWs, especially native wildflowers adapted to Florida's environment (plants often referred to as Florida ecotypes), began to be more fully recognized in the 1980s (1). Today the ecological value and sustainability of using native wildflowers adapted to specific regions of the country is widely acknowledged (6). When plantings of these types of wildflowers are established and managed appropriately, both maintenance costs and the need to replant are minimized.

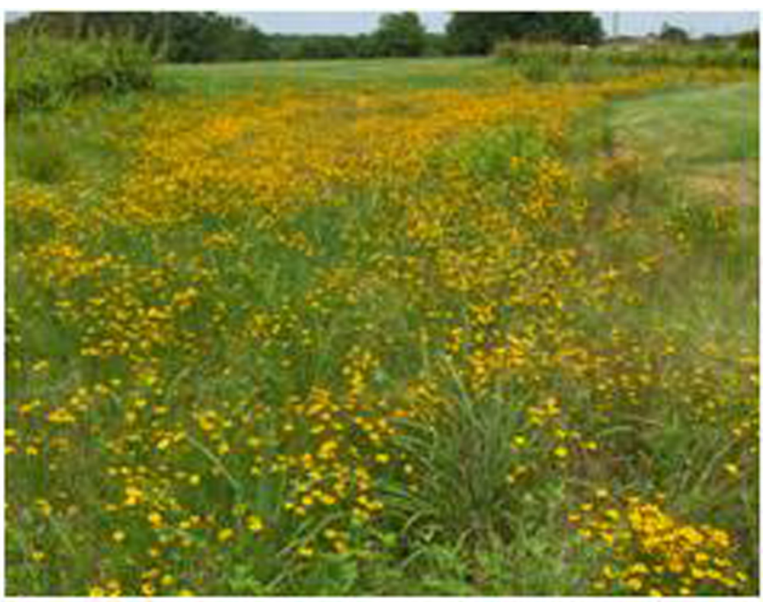

Figure 1. A swale planting of Leavenworth's tickseed.

1. This document is ENH1104, one of a series of the Environmental Horticulture Department, Florida Cooperative Extension Service, Institute of Food and Agricultural Sciences, University of Florida. Original publication date, April 2009. Visit the EDIS Web site at http://edis.ifas.ufl.edu.

2. Jeffrey G. Norcini, formerly associate professor and native wildflower specialist, Environmental Horticulture Department, North Florida Research and Education Center (NREC)--Quincy, FL; Anne L. Frances, Ph.D., and Carrie Reinhardt Adams, assistant professor and restoration horticulture specialist, Environmental Horticulture Department, Institute of Food and Agricultural Sciences, University of Florida, Gainesville, FL.

The use of trade names in this publication is solely for the purpose of providing specific information. UF/IFAS does not guarantee or warranty the products named, and references to them in this publication does not signify our approval to the exclusion of other products of suitable composition. Use pesticides safely. Read and follow directions on the manufacturer's label.

The Institute of Food and Agricultural Sciences (IFAS) is an Equal Opportunity Institution authorized to provide research, educational information and other services only to individuals and institutions that function with non-discrimination with respect to race, creed, color, religion, age, disability, sex, sexual orientation, marital status, national origin, political opinions or affiliations. U.S. Department of Agriculture, Cooperative Extension Service, University of Florida, IFAS, Florida A. \& M. University Cooperative Extension Program, and Boards of County Commissioners Cooperating. Interim Dean Millie Ferrer. 


\section{Leavenworth's Tickseed}

Leavenworth's tickseed is a wildflower that occurs almost exclusively in Florida, with the plant's only known occurrence outside of Florida being in two Alabama counties (12; M. Nishino, pers. comm). Although Leavenworth's tickseed has been documented in about 75 percent of Florida's counties (14), horticulturalists suspect that Leavenworth's tickseed probably occurs in nearly all Florida counties given that this wildflower's common habitats -- pine flatwoods, savannas, and moist, disturbed sites (13), such as roadside right-of-way ditches and swales -- are widespread throughout Florida (Fig. 1).

Leavenworth's tickseed is an upright plant that grows 1 1/2 - 3 feet tall. However, on roadside ROWs, Leavenworth's tickseed plants might be shorter if they are in the mow zone (Fig. 2). Leaf shape is highly variable, ranging from simple, narrow, lance-shaped leaves to narrow, bipinnately compound leaves (2). Flowers have showy, yellow petals (ray flowers) with a brownish center (disk flowers). Typically, Leavenworth's tickseed flowers are about 1/2 - 1 1/4 inches in diameter. However, flowers of naturally occurring South Florida populations of Leavenworth's tickseed tend to be smaller than naturally occurring populations of this plant in North Florida (2; Gary Henry, pers. comm.).

Under natural conditions in North Florida, Leavenworth's tickseed is mainly a late spring and summer blooming annual. In Central Florida and South Florida, however, Leavenworth's tickseed sometimes becomes a short-lived herbaceous perennial, especially in populations in which flowering is limited or prevented by mowing. In South Florida, Leavenworth's tickseed blooms year round (13) although spring is this wildflower's peak flowering season there.

Establishing a sustainable population of Leavenworth's tickseed requires the following:

1. An appropriate site,

2. Site preparation practices that minimize weed interference,
3. Timely sowing of seeds at an appropriate rate, and

4. Cultural practices that favor population sustainability.

Recommendations in this publication are based on a Central Florida ecotype of Leavenworth's tickseed (the only ecotype being sold as of fall 2008), including research and anecdotal evidence about establishment, maintenance, and performance of Florida ecotypes of native wildflowers under roadside or simulated roadside conditions in North Florida, Central Florida, and South Florida $(5,11)$.

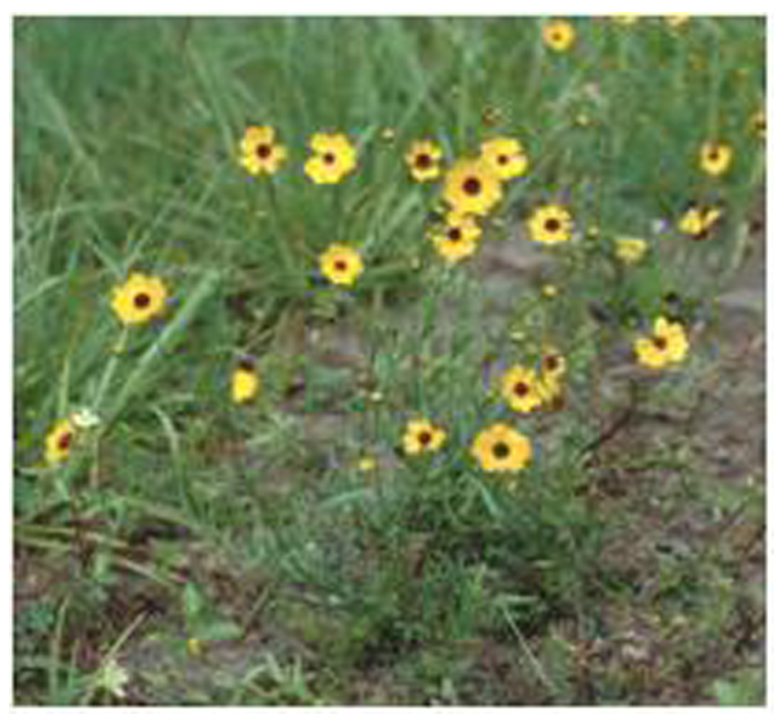

Figure 2. Leavenworth's tickseed on a roadside right of way.

\section{Ecotypes}

When native wildflowers are used in ROWs, we strongly encourage the use of seeds of ecotypes that

1. Originate from and are adapted to Florida's ecoregions and

2. That have been produced in a manner that maximizes genetic diversity of the harvested seeds.

Genetically diverse, commercially produced crops of Leavenworth's tickseed are likely to be those that have been harvested throughout the season by vacuuming seed off landscape fabric $(3,10)$ or by hand harvesting from each plant. The use of 
genetically diverse Florida ecotypes facilitates establishment and survival. The origin of these ecotypes makes them well suited for Florida's environment, and the genetic diversity enhances the likelihood of the long-term survival of the planting. Also, by using Florida ecotypes, the risk of genetically contaminating wild populations of Leavenworth's tickseed is minimized. For more information about ecotypes and issues regarding the use of native plants, see Native Plants: An Overview (9).

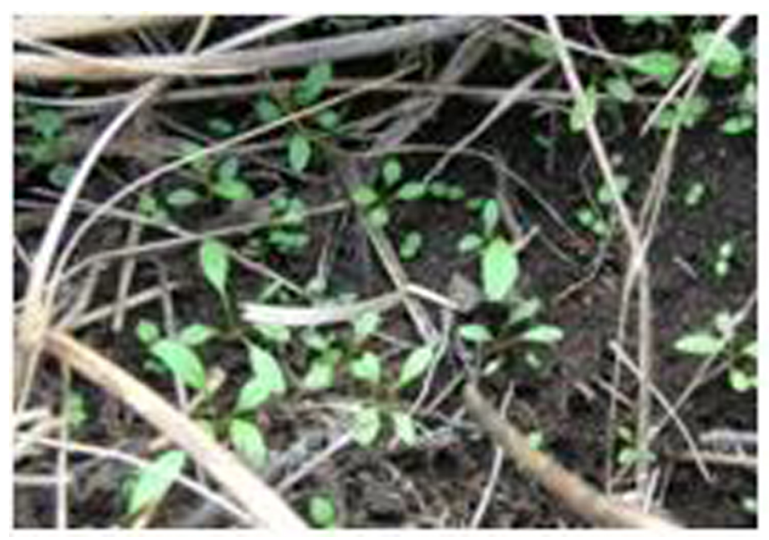

Figure 3. Leavenworth's tickseed seedings on a roadside right of way.

\section{Site Selection}

\section{Location}

The Central Florida ecotype of Leavenworth's tickseed seems to be well suited for roadside ROWs throughout Florida $(2,3)$.

Moist sites in the areas listed below are good locations to establish Leavenworth's tickseed plantings -- based on aesthetic appeal to the public, as well as on maintenance practices, safety considerations, and economic issues. Keep in mind, however, Leavenworth's tickseed's low salt tolerance makes this wildflower unsuitable for sites subject to flooding by brackish or salt water (7).

\section{- Rural areas}

- Sites that require mowing by mowers that are small to medium-sized or require string trimming

- Swales, ditches
- Moist portion of retention pond slopes

- Bottom of retention basins that are periodically inundated

- Interchanges, especially infields with soils that are too wet and soft for mowers

- Rest areas / welcome centers

\section{Site Characteristics}

Since Leavenworth's tickseed is a facultative wetland species (14), the ideal ROW site for Leavenworth's tickseed has soil that is moist to slightly moist. Successfully establishing a sustainable planting is more likely in sites with limited competition from weeds or turfgrasses. Avoid sites with Panicum repens (torpdeograss), Cyperus species (nutsedges or nutgrasses), Rubus species (blackberry and dewberry), and Smilax species (greenbrier or catbrier) as these plants are very difficult to control in a wildflower planting. Also avoid relatively dry sites in which bahiagrass predominates. Leavenworth's tickseed can be established in such sites, but the population will probably decline over two to three years (5). Also avoid highly compacted soils as establishment in such soils will be poor.

\section{Site Preparation}

A "no till" approach will facilitate successful Leavenworth's tickseed establishment. Tilling will promote germination of weeds and sedges in the seed bank.

Competition is one of the primary reasons that wildflower plantings fail. Leavenworth's tickseed establishment can be greatly increased by eradicating weeds and turfgrasses with an herbicide. About four weeks before sowing seeds of Leavenworth's tickseed, apply a nonselective, translocated herbicide that contains only glyphosate or glufosinate as an active ingredient. Make a second application about two weeks later (5).

About two weeks after the second application, mow the dead vegetation close to the soil. Use a flail mower to minimize the amount of clippings and thatch, which will allow seeds to reach the soil (5). 
Around ponds, streams, and other bodies of water, use an herbicide specifically designed for such use. Glufosinate cannot be used in areas where surface water is present. Control of Hard to Manage Weeds along Highway Rights-of-Way (4) is a UF/IFAS publication that contains recommendations for controlling weeds that occur in and around bodies of water.

CAUTIONARY NOTE: Although establishment of other native species has been improved using the herbicide imazapic (Plateau ${ }^{\circledR}$, BASF; Panoramic 2SL, Alligare; Impose ${ }^{\mathrm{TM}}$, Makhteshim Agan of North America), Leavenworth's tickseed establishment will likely not be improved with use of imazapic, and growth of Leavenworth's tickseed may be significantly stunted due to use of this herbicide (5).

\section{Sowing Seed}

\section{Seed Source}

Seeds of the Central Florida ecotype of Leavenworth's tickseed are available from the Wildflower Seed and Plant Growers Association, Inc. (also known as the Florida Wildflowers Growers Cooperative). Check their Web site for seed availability (http://www.floridawildflowers.com/). If seeds of Leavenworth's tickseed are not offered, contact the Growers Cooperative (businessmanager@floridawildflowers.com) to learn when seeds will be available or whether a grower has held some seeds in stock to sell directly. Currently, co-op members can keep 20 percent of their seeds to sell on their own.

\section{Time of Year}

Throughout Florida, seeds of Leavenworth's tickseed may be sown from late August to mid-October. However, some research-based evidence suggests that seeds could be planted at other times of the year if necessary (8). This research indicates that nondormant seeds will germinate under temperatures ranging from those typical of North Florida winters -- low 40s at night and mid-to-high 60 s during the day -- to the high summer temperatures that occur throughout the state - low 70s at night and low-to-mid 90s during the day.
Those sowing seeds during the winter in North Florida should be aware that seedling development will be slow, and seedlings might be susceptible to freeze or to frost injury because of limited time for hardening off.

\section{Seeding Rate}

Ideally, seeding rates should be determined for each species based on the following calculation: first, determine the number of viable seeds per acre or $1000 \mathrm{ft}^{2}$ that will result in a sustainable stand of wildflowers. (See instructions in box on Page 5, titled, How to Calculate Seeding Rate.) Next, convert that number of seeds to pounds.

However, because the number of viable seeds per acre (or per $1000 \mathrm{ft}^{2}$ ) is lacking or limited, bulk seeding rates are commonly used. Keep in mind that use of a bulk seeding rate can result in substantially more seeds being sown than necessary. While overseeding might not be an issue for relatively inexpensive seeds, ecotype seeds are expensive. The next-best alternative is to sow seeds on a "pounds of Pure Live Seed (PLS) per acre" basis (see instructions in box, below). Leavenworth's tickseed sown at $3 \mathrm{lb}$ PLS per acre will produce a good stand, provided that site-preparation guidelines in this publication are followed (5).

\section{Seeding Equipment}

Sow seeds with a seed drill or mechanical planter at depth of $1 / 8$ inch or less. If broadcasting seeds with a hand-operated spreader, increase seed-to-soil contact with a rubber-tired roller, turf roller, or similar equipment.

\section{Maintenance}

\section{Irrigation}

Moisture is essential for good germination, emergence, and establishment (Fig. 3). If rainfall is limited and irrigation is available, apply $1 / 4-1 / 2$ inch twice per week for two to four weeks after sowing seeds, with the higher amounts and frequency in sandier soils. However, such irrigation is probably not practical for large plantings. 


\section{Viable vs. Nonviable Seeds / 'Bulk Seed' vs. 'Pure Live Seed'}

Viable vs. Nonviable Seeds For seed producers and end users, seeds are classified as either viable or nonviable. A seed is deemed viable only if it is capable of germinating and producing normal plants under field conditions. To determine the percentage of viable seeds within a seed lot, a seed technologist conducts two tests. First, a germination test is conducted to determine the percentage of seeds that develop into normal seedlings within the allotted time of the germination test. A normal seedling possesses all of the structures necessary for the seedling to develop normally. If any of the essential structures are lacking or underdeveloped, or if the seedling is obviously infested with a bacteria or fungus, the seedling is deemed nonviable. Hence, a 'live' seed is not necessarily viable. At the conclusion of the germination test, all nongerminated, nondiseased seeds are subjected to a viability test, which typically is a tetrazolium (TZ) test. Tetrazolium is a colorless chemical that stains living tissue pink to red. Seeds subjected to the TZ test are deemed viable if the structures essential for germination and normal seedling development are stained pink to red. Seeds that test positive in a postgermination TZ test are classified as dormant; some labs refer to these seeds as 'hard.' Accurate $\mathrm{TZ}$ testing and interpretation of $\mathrm{TZ}$ test results requires considerable skill and experience.

Bulk Seed vs. Pure Live Seed A bag of seeds contains viable wildflower seeds, inert matter (nonviable seeds and pieces of leaves, stems, flowers) and possibly even some viable weed seeds. The total contents of the bag are referred to as bulk seed. The number of pounds of Pure Live Seed(s) in a bag is a function of viability and purity and is based on weight. However, since the percentage of viable seeds is determined under lab conditions, it is unlikely that all viable seeds will germinate and develop into mature plants under field conditions.

PLS (lb) $=\underline{\text { Total weight of seeds in bag (lb) } \times \% \text { purity } \times \% \text { viable seeds }}$ 10,000

where the $\%$ viable seeds $=\%$ germination $+\%$ dormant $($ often called hard $)$ seeds

For example, there are $81 \mathrm{lb}$ PLS in a $100 \mathrm{lb}$ bag of bulk seed that has $90 \%$ pure seed, with the pure seed being $90 \%$ viable $(81=[100 \times 90 \times 90] / 10,000)$.

The bulk seed weight in the bag, \% purity, \% germination, and \% dormant (or hard) seeds should always be on the seed label per Florida seed law specifications. The total percent viable seeds might also be listed on the label; if listed, simply use the total percent viable seeds in the equation above.

Figure 4. How to Calculate Seeding Rate

\section{Weed Control}

Competition, including that from grasses, is one of the primary reasons that wildflower plantings fail to establish or deteriorate a year or two after establishment. Once seedlings have become established, grasses can be eliminated -- or at least suppressed -- with Acclaim Extra (fenoxaprop; Bayer Environmental Science, Montvale NJ). Acclaim Extra is the only herbicide labeled for grass control in tickseed (Coreopsis) species. Use a nonionic surfactant to improve efficacy; do not use a crop oil as it could injure Leavenworth's tickseed.

\section{Mowing}

\section{General Guidelines}

Timing mowing cycles to flowering and seed set is the optimal method to determine mowing cycles as it will help to ensure establishment of a planting that is sustainable over the long term. Avoid mowing when Leavenworth's tickseed flowering stems start elongating and when plants are flowering and seeds are maturing. Seeds need about three to four weeks to mature after an individual flower has bloomed. The general recommendation for North Florida and Central Florida is to avoid mowing from April through September. In South Florida, avoid mowing from January to June. Realize, though, that weather 
can alter flowering and seed set by two to four weeks, and some plants in south Florida can flower at any time of the year. However, following the guidelines above will ensure re-seeding from most plants in a stand.

Stands of Leavenworth's tickseed can be mowed as few as two times per year, but no more than six mowing cycles should be necessary (5). Excessive mowing will cause the stand to decline (5). The final mowing cycle of the year can be a "clean up mowing" in very late fall in north and central Florida. Since Leavenworth's tickseed is mainly an annual, ensuring seed set is critical to sustaining the population over time.

\section{During Establishment}

For newly planted sites in which vegetation was killed with herbicide prior to seeding, one or two mowing cycles will probably be all that is needed through February to minimize growth of cool-season broadleaf weeds in North Florida and Central Florida.

\section{Fertilization}

Supplemental fertilization is not recommended. Since plantings will be mowed, nutrients will be recycled as the clippings decompose. Supplemental fertilization will promote weed growth and could make Leavenworth's tickseed more susceptible to drought stress, as well as to insects and diseases.

\section{References}

1) Florida Department of Transportation, Environmental Management Office. 1994. Wildflowers in Florida. Florida Department of Transportation, Tallahassee, FL. 30 pp.

2) Czarnecki II, D.M., J.G. Norcini, and Z. Deng. 2007. Phenotypic diversity of Coreopsis leavenworthii (Asteraceae). Native Plants Journal 8:45-57.

3) Czarnecki II, D.M., M.N. Rao, J.G. Norcini, F.G. Gmitter Jr., and Z. Deng. 2008. Genetic diversity and differentiation among natural, production, and introduced populations of Coreopsis leavenworthii. Journal of the American Society for Horticultural Science 133:1-8.

4) Ferrell, J. and K. Langeland. 2007. Control of Hard to Manage Weeds along Highway Rights-of-Way. EDIS Publ. SS AGR 275, http://edis.ifas.ufl.edu/pdffiles/AG/AG28000.pdf. Department of Agronomy, Fla. Coop. Ext. Serv., Institute of Food and Agricultural Sciences, University of Florida, Gainesville, FL.

5) Frances, A.L. 2008. Establishment and management of native wildflowers on Florida roadsides and former pastures, PhD Dissertation. University of Florida, Gainesville, FL.

6) Harper-Lore, B.L. and M. Wilson (Editors). 1999. Roadside Use of Native Plants. Water and Ecosystems Team, Office of Nat. Environ., Federal Highway Admin., Washington, D.C.

7) Gann, G.D., M.E. Abdo, J.W. Gann, G.D. Gann, Sr., S.W. Woodmansee, K.A. Bradley, E. Verdon and K.N. Hines. 2005-2008. Natives For Your

Neighborhood: Coreopsis leavenworthii. The Institute for Regional Conservation, Miami.

http://www.regionalconservation.org/beta/nfyn/ plantdetail.asp?tx=Coreleav (accessed October 30, 2008).

8) Kabat, S.M., J.G. Norcini, and B. Dehgan. 2007. Effect of light and temperature on germination of Leavenworth's coreopsis (Coreopsis leavenworthii). Native Plants Journal 8:236-247. 
9) Norcini, J.G. 2006. Native plants: An Overview.

EDIS Publ. ENH 1045, http://edis.ifas.ufl.edu/pdffiles/EP/EP29700.pdf. Department of Environmental Horticulture, Fla. Coop. Ext. Serv., Institute of Food and Agricultural Sciences, University of Florida, Gainesville, FL.

10) Norcini, J.G. 2006. Seed production of Leavenworth's coreopsis. EDIS Publ. ENH 868, http://edis.ifas.ufl.edu/document_ep122. Department of Environmental Horticulture, Fla. Coop. Ext. Serv., Institute of Food and Agricultural Sciences, University of Florida, Gainesville, FL.

11) Norcini, J. and J. Aldrich. 2003. Wildflower "sowing date" demonstration spring update. NFREC Newsletter. Vol. 10, Issue 5, May 12, 2003.

12) U.S. Dept. Agric., Nat. Res. Cons. Serv. 2008.

PLANTS profile: Coreopsis leavenworthii Torr. \& A. Gray. The PLANTS database. National Plant Data Center, Baton Rouge, LA 70874-4490 USA. http://plants.usda.gov/java/profile?symbol=COLE3 (accessed July 20, 2008).

13) Wunderlin, R. P. and B. F. Hansen. 2003. Guide to the vascular plants of Florida, second edition. University Press of Florida, Gainesville, FL.

14) Wunderlin, R.P. and B.F. Hansen. 2008. Coreopsis leavenworthii. Atlas of Florida vascular plants.

http://florida.plantatlas.usf.edu/Plant.aspx ?id=1180 (accessed April 8, 2009). [S. M. Landry and K. N. Campbell, application development.] Florida Center for Community Design and Research. Institute for Systematic Botany, University of South Florida, Tampa. 